\title{
A phosphoinositide-based model of actin waves in frustrated phagocytosis
}

Marco A. Avila Ponce de Leon

University of Minnesota - Twin Cities, ponce018@umn.edu

Follow this and additional works at: https://scholarscompass.vcu.edu/bamm

Part of the Medicine and Health Sciences Commons, Physical Sciences and Mathematics Commons, and the Systems Biology Commons

https://scholarscompass.vcu.edu/bamm/2020/poster/8

This Event is brought to you for free and open access by the Dept. of Mathematics and Applied Mathematics at VCU Scholars Compass. It has been accepted for inclusion in Biology and Medicine Through Mathematics Conference by an authorized administrator of VCU Scholars Compass. For more information, please contact libcompass@vcu.edu. 
Phagocytosis is a complex process by which phagocytes such as lymphocytes or macrophages engulf and destroy foreign bodies called pathogens in a tissue. The process is triggered by the detection of antibodies that trigger signaling mechanisms that control the changes of the cellular cytoskeleton needed for engulfment of the pathogen. A mathematical model of the entire process would be extremely complicated, because the signaling and cytoskeletal changes produce large mechanical deformations of the cell. Recent experiments have used a confinement technique that leads to a process called frustrated phagocytosis, in which the membrane does not deform, but rather, signaling triggers actin waves that propagate along the boundary of the cell. This eliminates the large-scale deformations and facilitates modeling of the wave dynamics. Herein we develop a model of the actin dynamics observed in frustrated phagocytosis and show that it can replicate the experimental observations. We identify the key components that control the actin waves and make a number of experimentally-testable predictions. In particular, we predict that diffusion coefficients of membrane-bound species must be larger behind the wavefront to replicate the internal structure of the waves. Our model is a first step toward a more complete model of phagocytosis, and provides insights into circular dorsal ruffles as well. 